\title{
How smartphone advertising influences consumers' purchase intention
}

\author{
José Martins $^{\mathrm{a}, *}$, Catarina Costa ${ }^{\mathrm{b}}$, Tiago Oliveira ${ }^{\mathrm{b}}$, Ramiro Gonçalves ${ }^{\mathrm{a}}$, Frederico Branco ${ }^{\mathrm{a}}$ \\ a University of Trás-os-Montes e Alto Douro, INESC TEC, Vila Real, Portugal \\ ${ }^{\mathrm{b}}$ NOVA, Information Management School (NOVA IMS), Lisboa, Portugal
}

\section{A R T I C L E I N F O}

\section{Keywords:}

Advertising value

Flow experience

Smartphone advertising

Purchase intention

\begin{abstract}
A B S T R A C T
In the last decade, the use of smartphones has grown steadily. The way consumers interact with brands has changed owing to the accessibility of internet connection on smartphones, and ubiquitous mobility. It is crucial to understand the factors that motivate consumers to interact with smartphone advertisements and therefore what stimulates their decision to purchase. To achieve this goal, we proposed a conceptual model that combines Ducoffe's web advertising model and flow experience theory. Based on the data collected from 303 Portuguese respondents we empirically tested the conceptual model using a partial least squares (PLS) estimation. The results showed that advertising value, flow experience, web design quality, and brand awareness explain purchase intention. The study provides results that allow marketers and advertisers to understand how smartphone advertisements contribute to consumer purchase intention.
\end{abstract}

\section{Introduction}

The number of smartphone users has been increasing significantly because of the growth of the smartphone industry, which develops new operating systems and a proliferation of applications. According to Gartner (2016) global sales of smartphones to end users totalled 349 million units in Q1 2016, a 3.9\% increase over the same period in 2015. Moreover, smartphone sales represented $78 \%$ of total mobile phone sales in Q1 2016. Smartphones have been influencing the way people communicate with each other, becoming a near necessity in both private and professional lives (Derks, Bakker, Peters, \& van Wingerden, 2016). The unprecedented growth of smartphones has attracted academic attention, hoping to determine the motivations that explain smartphone use (Park, Kim, Shon, \& Shim, 2013; Yeh, Wang, \& Yieh, 2016).

Earlier studies focused mainly on antecedents of advertising value and flow experience on mobile advertising, to study attitude toward mobile advertising or intention to read or click (Liu, Sinkovics, Pezderka, \& Haghirian, 2012; Yang, Kim, \& Yoo, 2013). There is little research about what leads to advertising value, flow experience, and purchase intention on smartphone advertising (Kim \& Han, 2014). Therefore, the aim of this study is to analyse the factors that influence consumers' purchase intention after seeing smartphone advertisements. To do so, we developed a model that combines Ducoffe's web advertising model, flow experience theory and three additional variables (emotional value, web design quality, and brand awareness) to understand the antecedents of purchase intention on smartphone advertising. The research questions (RQs) that emerged are as follows:

RQ1 - What are the factors that influence advertising value and flow experience?

RQ2 - Do emotions add significance to advertising value in smartphone advertisements?

RQ3 - Does web design quality influence flow experience in smartphone advertisements?

RQ4 - Does brand awareness play an important role in forming purchase intention in smartphone advertisements?

The contributions of this research are threefold. Firstly, it will be a guideline for marketers and advertisers to understand the factors that play an important role in smartphone advertising. Secondly, it provides valuable insights on how smartphone advertisements contribute to forming consumer purchase intention. Thirdly, we investigate the elements that influence best communication strategies for brands in the smartphone advertising market.

This article is structured as follows: Section 2 contains the theoretical background, i.e., the concept of mobile advertising, smartphone advertising and purchase intention, and theoretical foundation. Then, in Section 3 it presents the conceptual model, followed by Section 4 which covers the method used in the research. Sections 5 and 6 contain data analysis and discussion, respectively. Conclusions are in Section 7.

\footnotetext{
* Corresponding author.

E-mail addresses: jmartins@utad.pt (J. Martins), catarinacavaleirocosta@gmail.com (C. Costa), toliveira@novaims.unl.pt (T. Oliveira), ramiro@utad.pt (R. Gonçalves), fbranco@utad.pt (F. Branco).
} 


\section{Theoretical background}

\subsection{The concepts of mobile advertising, and smartphone advertising}

Mobile advertising is defined by The Mobile Marketing Association as " $a$ form of advertising that transmits advertisement messages to users via mobile phones or other wireless communication devices" (Chen \& Hsieh, 2012). By incorporating mobile advertising techniques in their communication strategies, retailors, services providers and manufacturers can create more dynamic offers and campaigns. From a theoretical perspective, in order to understand how campaigns can reach successful levels, one must know how to ensure alignment between all context variables, the advertising goals, the stakeholders, market conditions, and the chosen mobile ad elements (Grewal, Bart, Spann, \& Zubcsek, 2016).

Smartphones, different from standard mobile phones in terms of the operating system, have been attracting a substantial number of users and have become a perceived necessity in personal and work lives. People use them for social networking purposes, for features and functions like reading e-books, answering e-mails, sending messages, and playing games. The Smartphone is a quite new technology and it has received minor attention in academic research in terms of understanding users' mind-sets about the adoption of smartphones (Joo \& Sang, 2013). Nevertheless, smartphone advertisements play an increasing role in the decision-making process in supporting consumer purchases (Kim \& Han, 2014).

Advertisements on smartphones have become more sophisticated, adapting to device screens that are not suitable for showing traditional online advertising (pop up, pop under, video, and display ads).

\subsection{The concept of purchase intention}

Purchase intention indicates likelihood that consumers will plan or be willing to purchase a certain product or service in the future $\mathrm{Wu}$, Yeh, \& Hsiao, 2011). Past research has demonstrated that an increase in purchase intention reflects an increase in the chance of purchasing. If consumers have a positive purchase intention, then a positive brand engagement will promote that purchase. Regarding the context of smartphones, one needs to consider purchase intention as the desire of consumers to make a purchase through the mobile application (Chen, Hsu, \& Lin, 2010). Some of the most relevant research on mobile purchase intention is summarized in Table 1.

In their most recent research, Zubcsek, Katona, and Sarvary (2017) present several arguments supporting the assumption that consumers' movement patterns tend to represent their product preferences, which should be used by marketers to improve the provided commercial offer. In line with this, Shen (2015) argues that not only is mobile shopping increasing to the point of becoming part of many people's routine, but there is also a set of determinants, such as attitudes, subjective norms, and perceived behavioral control that tend to impact the customer intention to purchase. Hence, product information in mobile advertising should take into consideration these determinants to be well accepted by customers and to have the desired trigger effect.

\subsection{Theoretical foundation}

\subsubsection{Ducoffe's web advertising model}

Ducoffe (1995) developed an approach to study the effectiveness of attitude toward web advertising, focusing on advertising value. In order to understand what makes an advertisement valuable, Ducoffe (1995) found the antecedents (i.e., informativeness, irritation, and entertainment) of advertising value on the World Wide Web. Firstly, informativeness, described as the ability of advertising to inform consumers of product types. Secondly, irritation reflects the techniques employed by advertisers that annoy, offend, insult, or manipulate consumers. Consequently, techniques are perceived as unwanted, irritating consumers. Thirdly, entertainment is perceived as pleasant or likeable advertising and has a positive impact on brand attitudes. These three determinants were the starting point to justify how consumers evaluate the value of advertising. The addition of credibility by Brackett and Carr (2001) and incentives by Kim and Han (2014) as antecedents of advertising value came later. Varnali, Yilmaz, and Toker (2012) describe incentive as generic monetary gains (lotteries, discounts, prepaid credits, and gifts).

\subsubsection{Flow experience theory}

Csikszentmihalyi (1975) pioneered flow construct. Flow illustrates the best feelings and the most enjoyable experiences possible in human lives as "the bottom line of existence". By definition, flow is a psychological state in which an individual feels cognitively efficient, motivated, and happy. Researchers have started to recognize the value of this theory in understanding people's behaviour while using the web (Hoffman \& Novak, 2009; Novak, Hoffman, \& Yung, 2000). The concept of flow was first applied to the experiences of web users by Hoffman and Novak (1996) in an examination of online marketing activities.

\section{Conceptual model}

\subsection{The conceptual model}

The conceptual model, as shown in Fig. 1, is based on Ducoffe's web advertising model and flow experience. The goal of this research is to determine how consumers perceive the antecedents of the interaction with smartphone advertisements, and consequently how this influences their purchase intention. The constructs, advertising value, and flow experience have five common variables: (1) informativeness; (2) credibility; (3) entertainment; (4) irritation; and (5) incentives. A new variable was added to advertising value, i.e., emotional value. Similarly, the web design quality variable was added to flow experience. We added brand awareness and the antecedent emotional value. Purchase intention is depicted as the consequence of advertising value, flow experience, web design quality, and brand awareness. Each of these constructs is discussed in the following sections.

Table 1

Earlier research studies on mobile purchase intention.

\begin{tabular}{|c|c|c|}
\hline Topic & Research & References \\
\hline $\begin{array}{l}\text { Information credibility and purchase } \\
\text { intention }\end{array}$ & $\begin{array}{l}\text { Discuss how information credibility and user-generated content might impact the product quality } \\
\text { and the customer purchase intention }\end{array}$ & $\begin{array}{l}\text { Flanagin, Metzger, Pure, Markov, } \\
\text { and Hartsell (2014) }\end{array}$ \\
\hline $\begin{array}{l}\text { Purchase intention in social network } \\
\text { sites }\end{array}$ & $\begin{array}{l}\text { Authors studied the relationship between eWOM, value co-creation, and purchase intention when } \\
\text { customers are using SNS }\end{array}$ & See-To and Ho (2014) \\
\hline $\begin{array}{l}\text { Risk perceptions and online purchase } \\
\text { intention }\end{array}$ & $\begin{array}{l}\text { Research on the influence of online shopping experience on perception of risks associated with } \\
\text { online shopping and how this influences online purchase intentions }\end{array}$ & Dai, Forsythe, and Kwon (2014) \\
\hline $\begin{array}{l}\text { Facebook advertising effect on } \\
\text { purchase intention }\end{array}$ & $\begin{array}{l}\text { Discuss how customer perception toward social media advertising impacts the relationship with } \\
\text { brands, hence triggering the purchase intention. }\end{array}$ & Dehghani and Tumer (2015) \\
\hline Mobile shopping & $\begin{array}{l}\text { Authors present an extension to Technology Acceptance Model that included perceived } \\
\text { enjoyment and satisfaction as the added constructs, aiming to explain customers' acceptance of } \\
\text { m-shopping. }\end{array}$ & Agrebi and Jallais (2015) \\
\hline
\end{tabular}




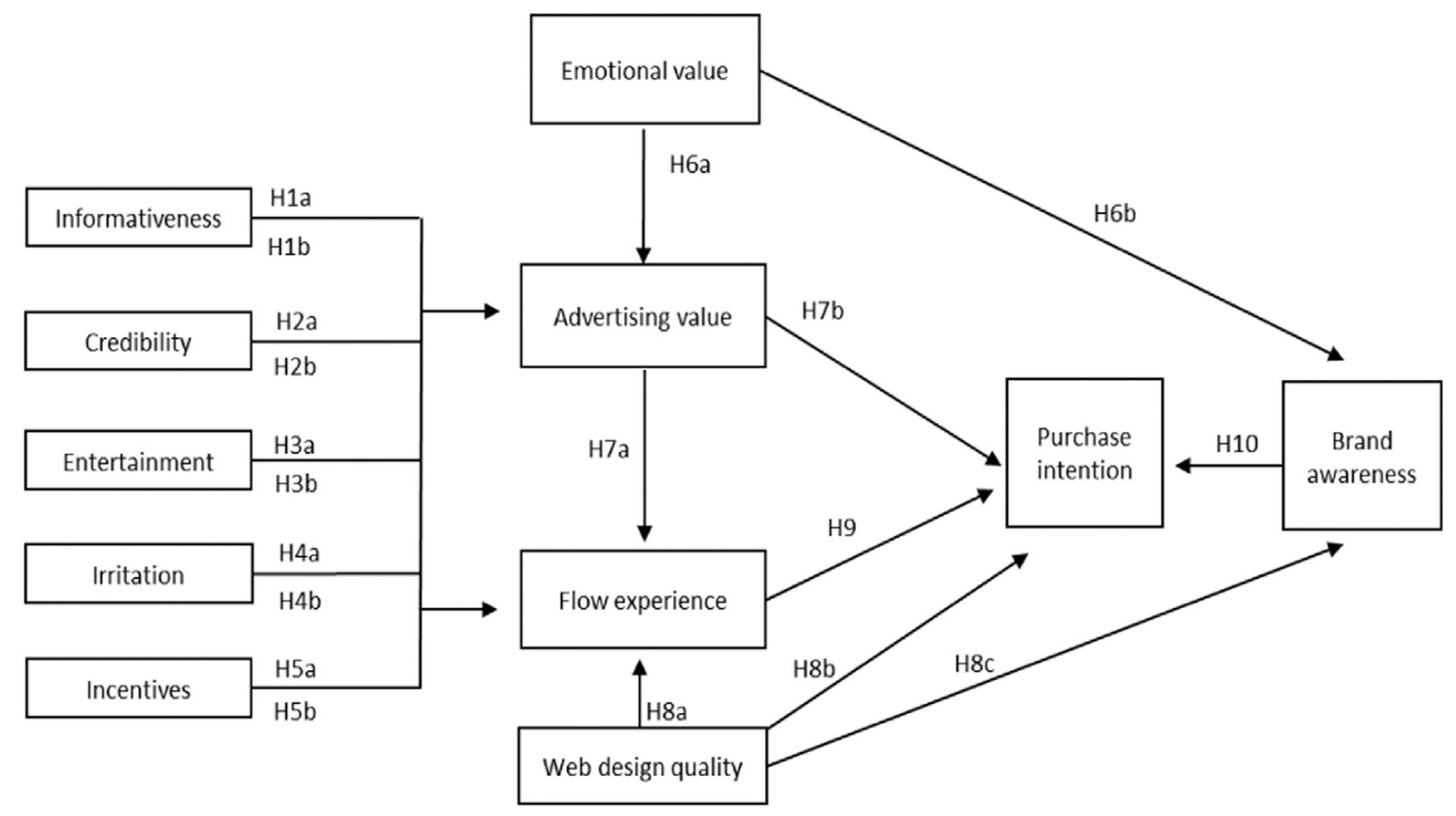

Fig. 1. - Conceptual model.

\subsection{Hypotheses}

In a mobile devices context, information is considered as a valuable incentive because consumers react very positively to advertising (Aitken, Gray, \& Lawson, 2008). Consumers do not feel annoyed if mobile advertisements provide appropriate information. Scharl, Dickinger, and Murphy (2005) concluded that consumers are likely to purchase advertised products if advertisers provide funny and entertaining SMS messages that are informative and relevant. Thus, informativeness is strongly related to perceived advertising value (Ducoffe, 1996). In addition, informativeness positively influences flow experience because it will affect consumer attention. The consumer focuses on product information messages, concentrating on their details, excluding irrelevant thoughts (Hoffman \& Novak, 1996; Li \& Browne, 2006). Thus:

H1. Perceived informativeness of smartphone advertisements is (H1a) positively associated with perceived advertising value and (H1b) positively associated with flow experience.

"The extent to which the consumer perceives claims made about the brand in ads to be truthful and believable", defines credibility (Mackenzie \& Lutz, 1989). Several empirical studies have demonstrated that advertisement credibility has a significant effect on attitudes toward advertising and behavioral intentions (Tsang, Ho, \& Liang, 2004; Zhang \& Mao, 2008). Advertising credibility is evaluated through the content of advertisements, being further influenced by a company's credibility and the holder of the message (Balasubraman, Peterson, \& Jarvenpaa, 2002). Thus, advertising credibility positively affects the perceived value of advertising. According to Yang et al. (2013) a consumer may avoid or not respond to advertising if they do not think mobile advertisements are trustworthy, not paying attention to the message. Therefore, the reliability of a mobile message is critical and consumers are able to experience flow state with a credible message (Choi, Hwang, \& McMillan, 2008). Thus:

H2. Perceived credibility of smartphone advertisements is (H2a) positively associated with perceived advertising value and ( $\mathrm{H} 2 \mathrm{~b}$ ) positively associated with flow experience.

Ducoffe (1995) confirmed that entertainment of advertising information is positively related to advertising value. Entertainment is the ability of an advertisement to promote enjoyment and create positive consumer attitudes by providing a form of escapism, diversion, aesthetic enjoyment, or emotional release (Elliott \& Speck, 1998; Shavitt, Lowrey, \& Haefner, 1998). In the advertising context, entertainment is pleasurable, enjoyable, and fun to watch (Schlinger, 1979). According to Sternthal and Craig (1973) entertaining advertisements attract consumers' attention, consequently the effectiveness of the advertisement increases. Coulter, Zaltman, and Coulter (2001) found that entertainment is an important value that consumers look for in advertising. Moreover, entertainment has recently become a factor that consumers expect when they view advertising. Entertainment positively influences consumer flow experience. Hence:

H3. Perceived entertainment of smartphone advertisements is (H3a) positively associated with perceived advertising value and (H3b) positively associated with flow experience.

Irritation refers to the extent to which consumers perceive that mobile advertisements are irritating or annoying, involving negative feelings toward the advertisements (Yang et al., 2013). Past research examined irritation as being negatively related to advertising value, reducing advertising effectiveness and the value perceived by consumers (Korgaonkar \& Wolin, 1999; Okazaki, 2004). Mobile advertising may provide information that is distracting and that overwhelms the consumer (Stewart \& Pavlou, 2002) and this can be perceived as an intrusion into the mobile consumer's privacy. According to Liu et al. (2012) consumers then feel confused about the advertising and react negatively to it, and irritation caused by incomprehensible or unwanted mobile advertising messages may reflect negatively on the perceived value of mobile advertising. Hence:

H4. Perceived irritation of smartphone advertisements is (H4a) negatively associated with perceived advertising value and (H4b) negatively associated with flow experience.

Incentives are major predictors of consumers' responses and entail monetary benefits such as discounts, coupons, gifts, and non-monetary benefits (Varnali et al., 2012). Incentives are considered to have an impact on consumer intentions to receive mobile advertising and provide specific financial rewards to consumers who agree to receive an advertisement (Tsang et al., 2004). Y. Kim and Han (2014) introduced the incentives in the Ducoffe (1995) model. They suggest increasing 
incentives for consumers receiving smartphone advertisements, affecting consumer flow experience. Their study reported that consumers are interested in tangible benefits and pay more attention to an advertising message for financial advantage. Thus, consumers perceive value in an advertisement with incentives. Consequently:

H5. Perceived incentives of smartphone advertisements is (H5a) positively associated with perceived advertising value and (H5b) positively associated with flow experience.

Past research studied emotion in the advertising field (Edell \& Burke, 1987). The utility derived from the feelings or affective states (i.e. enjoyment or pleasure) that a product generates defines emotional value. Emotional value toward a brand relates to positive feelings upon using the brand, which increases consumer loyalty toward the brand (Sweeney \& Soutar, 2001). When consumers view advertising, the information contained in it induces emotional responses and creates an attitude toward the brand. Hyun, Kim, and Lee (2011) defined emotional responses toward advertising as the set of emotional responses elicited during advertising viewing. We suggest the addition of emotional value to explain perceived adverting value and increasing brand awareness. Therefore:

H6. Perceived emotional value is (H6a) positively associated with advertising value and (H6b) positively associated with brand awareness.

Advertising value is a measure of advertising effectiveness, being defined as a "subjective evaluation of the relative worth or utility of advertising to consumers" (Ducoffe, 1995, p. 1). Perceived advertising value contributes to the growth of flow experience because consumers focus totally on the messages received, eliminating irrelevant thoughts (Hoffman \& Novak, 1996). Consumers evaluate the received messages as being worthy if they match their needs or include valuable information to purchase. Past research studied the relationship between advertising attitude and purchase intention (Tsang et al., 2004). However, there are few studies investigating the relationship between advertising value and purchase intention. Consumers show a favorable attitude to products or services when purchase intention increases (Ko, Cho, \& Roberts, 2005). Thus:

H7. Perceived advertising value is (H7a) positively associated with flow experience and (H7b) positively associated with purchase intention.

Web design is the set of elements that a consumer experiences on a web site - information search, product selection (Ha \& Stoel, 2009). Design factors - size of the advertisement, use of colour, music effects, presence of animation, and the length of the commercial are related to how effectively the advertisement is designed. Web site design affects online purchase intention. A poorly designed interface can disrupt a flow experience by demanding an excessive amount of attention, or contrarily, distracting the users. H. Kim and Niehm (2009) reported that web design quality positively influences consumer perception regarding the quality of information shown on the web site, and consequently affects brand perception as reliable. We include web design quality due to the lack of study about designing mobile advertisements. Accordingly:

H8. Perceived web design quality is (H8a) positively associated with flow experience, (H8b) positively associated with purchase intention, and (H8c) positively associated with brand awareness.

The concept of flow refers to optimal and enjoyable experiences when an individual engages in an activity with total involvement, concentration, and enjoyment. When consumers become absorbed in their activities, irrelevant thoughts and perceptions are filtered out. Researchers concluded that surfing the web is an activity that can facilitate the occurrence of flow (Chen, Wigand, \& Nilan, 1998; Hoffman \& Novak, 1996). The decision to interact with smartphone advertisements and whether to purchase advertised products or services or not is crucial for flow experience (Kim \& Han, 2014). Thus, consumers' flow experience positively influences purchase intention. Hence:

H9. Flow experience is positively associated with purchase intention.

Brand awareness is related to the strength of the brand node or trace in memory as reflected by consumers' ability to recall or recognize the brand under different conditions. Hence, only brands that consumers recognize can be identified, categorized, and ultimately purchased. The importance of brand awareness resides in the fact that consumers include it in their decision to purchase and evaluate the product. Regarding purchase intention, consumers' choice of a more familiar brand is usually higher than that of a less familiar brand (Hoyer \& Brown, 1990). We add brand awareness because past research has demonstrated that raising it increases the chance of the brand being considered for purchase (Washburn \& Plank, 2002). Thus:

H10. Brand awareness is positively associated with purchase intention.

\section{Methods}

\subsection{Measurement}

All constructs were adapted, with slight modifications, from the literature (see Appendix A). All the constructs were measured by using seven-point range scales in each item, ranging from "strongly disagree" (1) to "strongly agree" (7). The language of the constructs was modified to be suitable in the smartphone ad context. We also included four demographic questions relating to age, gender, education, and job. The questionnaire was uploaded to the web, to be divulged online, through surveymonkey.com.

\subsection{Data}

In July 2016 a pilot survey was conducted with 44 responses to refine the questions, obtain additional comments on the content and structure in order to decide which would be the final items to analyse. Respondents of the pilot test were asked to provide feedback and suggestions for improvement when instructions or questions were not clear. Respondents also answered all questions by following the instructions. The most important changes were in the items of emotion value (EV), web design quality (WDQ), incentives (INC), and purchase intention (PI), as they generated misunderstandings and users did not clearly understand the questions. For this reason and regarding the smartphone context, the items were modified by many suggestions about the phrasing and the overall structure of the questionnaire. The data from the pilot survey was not included in the main survey.

A survey was conducted to examine the hypotheses in this study. Respondents were those who have a smartphone and have had an experience viewing smartphone advertisements. The data were collected from smartphone consumers who had experienced SMS, MMS, keyword search, display, and rich media advertising. We carefully scrutinized the responses for each question. Improper responses such as having the same answers to all questions and incomplete responses were excluded from our sample. In total, 303 respondents successfully completed the questionnaire, which can be considered an adequate sample for a research of this kind (Baptista \& Oliveira, 2015; Hossein, 2015; Hsia, Chang, \& Tseng, 2014; Zhu, Chang, \& Luo, 2016). These valid responses were analysed to assess reliability, validity, and appropriateness for hypotheses testing.

We administered the questionnaires to people residing in Portugal, the 18th country in the World regarding smartphone penetration rate (Newzoo, 2017). The final sample comprised 303 individuals (see Table 2), in which $49 \%$ (151) are male and 51\% (152) are female. The average age is 33, the youngest respondent being 15 and the oldest 63 . 
Table 2

Survey respondent profile $(n=303)$.

\begin{tabular}{|c|c|c|c|c|c|c|c|}
\hline Measure & Item & $N$ & Percentage (\%) & Measure & Item & $N$ & Percentage $(\%)$ \\
\hline \multirow[t]{2}{*}{ Gender } & Male & 151 & 49.8 & Daily Internet usage time (using a smartphone) & Seldom & 13 & 4.3 \\
\hline & Female & 152 & 50.2 & & Under $1 \mathrm{~h}$ & 51 & 16.8 \\
\hline \multirow[t]{6}{*}{ Age } & Under 20 & 10 & 3.3 & & $1 \mathrm{~h}-2 \mathrm{~h}$ & 73 & 24.1 \\
\hline & $20-29$ & 133 & 43.9 & & $2 h-3 h$ & 61 & 20.1 \\
\hline & $30-39$ & 82 & 27.1 & & Over $3 \mathrm{~h}$ & 105 & 34.7 \\
\hline & $40-49$ & 52 & 17.2 & Frequency of reading or viewing of an & Seldom & 103 & 34.0 \\
\hline & $50-59$ & 24 & 7.9 & advertisement on a smartphone & $1-3$ per day & 80 & 26.4 \\
\hline & $60-69$ & 2 & 0.7 & & $>3$ per day & 80 & 26.4 \\
\hline \multirow[t]{6}{*}{ Education } & Junior high school & 6 & 2.0 & & 1 per $2-3$ days & 21 & 6.9 \\
\hline & High school & 28 & 9.2 & & 1 per $4-5$ days & 7 & 2.3 \\
\hline & Graduate & 135 & 44.6 & & 1 per week & 12 & 4.0 \\
\hline & Postgraduate & 59 & 19.5 & Last purchase of a smartphone & Under 6 months & 71 & 23.4 \\
\hline & Master & 70 & 23.1 & & $\begin{array}{l}6 \text { months - } \\
1 \text { year }\end{array}$ & 76 & 25.1 \\
\hline & Doctorate & 5 & 1.7 & & 1 year - 2 years & 92 & 30.4 \\
\hline \multirow[t]{5}{*}{ Job } & Unemployed & 6 & 2.0 & & 2 years -3 years & 38 & 12.5 \\
\hline & Student & 39 & 12.9 & & Over 3 years & 26 & 8.6 \\
\hline & Freelancer & 5 & 1.7 & How long respondent has used a smartphone & Under 6 months & 7 & 2.3 \\
\hline & Self-employed & 25 & 8.3 & & $\begin{array}{l}6 \text { months - } \\
1 \text { year }\end{array}$ & 17 & 5.6 \\
\hline & Employed & 228 & 75.2 & & 1 year - 2 years & 29 & 9.6 \\
\hline \multirow{6}{*}{$\begin{array}{l}\text { Internet usage period (using a } \\
\text { smartphone) }\end{array}$} & No use & 2 & 0.7 & & 2 years -3 years & 59 & 19.5 \\
\hline & Under 6 months & 8 & 2.6 & & Over 3 years & 191 & 63.0 \\
\hline & 6 months - 1 year & 15 & 5.0 & & & & \\
\hline & 1 year -2 years & 50 & 16.5 & & & & \\
\hline & 2 years -3 years & 61 & 20.1 & & & & \\
\hline & Over 3 years & 167 & 55.1 & & & & \\
\hline
\end{tabular}

\section{Results}

To examine the causal relationships and estimate the conceptual model, we used structured equation modeling (SEM). SEM has changed the nature of research in international marketing and management. It is a statistical technique for testing and estimating causal relationships using a combination of statistical data and qualitative causal assumptions (Henseler, Ringle, \& Sinkovics, 2009). The use of Partial Least Squares (PLS) is suitable and was considered the most appropriate method due to: (a) the early stage of theoretical development; (b) this conceptual model has not been tested in the literature and; (c) the conceptual model is considered to be complex. In the next two subsections we firstly examine the measurement model in order to assess indicator reliability, construct reliability, convergent validity, and discriminant validity. Secondly, we test the structural model. The software used for applying the method was PLS Smart 3.0 Software (Ringle, Wende, \& Will, 2005).

\subsection{Measurement model}

Firstly, in order to analyse the indicator reliability, the loadings should be higher than 0.7 (Chin, 1998; Hair \& Anderson, 2010; Henseler et al., 2009). All the items have loadings $>0.7$ (Table 3), confirming that the indicator reliability is achieved. Secondly, two criteria were used to examine the construct's reliability - Cronbach's alpha (CA) and composite reliability (CR). As seen in Table 3, all constructs have CR and CA > 0.7, approving construct reliability (J. Henseler et al., 2009). Thirdly, in order to assess convergent validity, the average variance extracted (AVE) should be at least 0.5 to be considered sufficient and explain more than half of the variance of its indicators on average (Hair \& Anderson, 2010; Henseler et al., 2009). As seen in Table 3, AVE for all the constructs are above 0.5, guaranteeing convergent validity.

Finally, the discriminant validity has three criteria. The first criterion is the Fornell-Larcker criterion, which demands that the root square of AVE (Table 4 in bold) for each latent variable should be greater than the correlation with any other latent variable (Fornell \& Larcker, 1981). In Table 4, we see that these criteria are achieved. The second criterion, the loading of each indicator is expected to be greater than all of its cross-loadings (Chin, 1998). This was also analysed and each construct has loadings with higher values than their cross loadings (Hair \& Anderson, 2010); this result is available from the author upon request. The Hetrotrait-Monotrait ratio (HTMT) table is available upon request, and all values are below the threshold of 0.9 (Jörg Henseler, Ringle, \& Sarstedt, 2015).

Therefore, all the measures satisfy the discriminant validity of the constructs. The assessment of the construct reliability, convergent validity and indicator reliability, produce satisfactory results, indicating that the constructs can be used to test the conceptual model.

\subsection{Structural model}

We demonstrated above that the measurement model is satisfactory. Now, it is possible to test the structural model. This article used a bootstrapping of 5000 resamples to estimate the statistical significance of path coefficients (Tenenhaus, Vinzi, Chatelin, \& Lauro, 2005). According to Chin (1998), the crucial criterion for assessing the structural model is the coefficient of determination $\left(\mathrm{R}^{2}\right)$ of the endogenous latent variables. $\mathrm{R}^{2}$ should be above 0.2 to be considered moderate. The results of the hypotheses of structural model are illustrated in Fig. 2.

First, the research explains $71.7 \%$ of variation in advertising value in the conceptual model. The hypotheses of informativeness $(\widehat{\beta}=0.133 ; \quad p<0.05)$, credibility $(\widehat{\beta}=0.334 ; p<0.01)$, entertainment $(\widehat{\beta}=0.205 ; \mathrm{p}<0.01)$, irritation $(\widehat{\beta}=-0.071$; $p<0.10)$, and incentives $(\widehat{\beta}=0.260 ; \mathrm{p}<0.01)$ are statistically significant. However, emotional value $(\widehat{\beta}=0.011 ; p>0.10)$ is not statistically significant. Therefore, hypotheses H1a, H2a, H3a, H4a, and H5a are supported, but H6a is not supported to explain advertising value.

Second, flow experience is explained by $67.4 \%$ of the variation in the conceptual model. The hypotheses that are statistically significant to explain flow experience are credibility $(\widehat{\beta}=0.208$; $p<0.01)$, entertainment $(\widehat{\beta}=0.164 ; \mathrm{p}<0.05), \quad$ irritation $(\widehat{\beta}=-0.084$; $\mathrm{p}<0.10)$, incentives $(\widehat{\beta}=0.321 ; \mathrm{p}<0.01)$, and advertising value $(\widehat{\beta}=0.288 ; \mathrm{p}<0.01)$. However, informativeness $(\widehat{\beta}=-0.156$; 
Table 3

Factor loading, composite reliabilities, Cronbach alpha and average variance extracted $(n=303)$.

\begin{tabular}{|c|c|c|c|c|c|c|c|c|c|}
\hline Constructs & Loadings & $\mathrm{CR}$ & $\mathrm{CA}$ & AVE & Constructs & Loadings & $\mathrm{CR}$ & $\mathrm{CA}$ & AVE \\
\hline Informativeness & & 0.957 & 0.941 & 0.849 & Flow experience & & 0.941 & 0.915 & 0.799 \\
\hline INF1 & 0.888 & & & & FE1 & 0.837 & & & \\
\hline INF2 & 0.930 & & & & FE2 & 0.904 & & & \\
\hline INF3 & 0.932 & & & & FE3 & 0.932 & & & \\
\hline INF4 & 0.935 & & & & FE4 & 0.899 & & & \\
\hline Credibility & & 0.967 & 0.955 & 0.882 & Emotional value & & 0.904 & 0.865 & 0.654 \\
\hline CRED1 & 0.919 & & & & EV1 & 0.852 & & & \\
\hline CRED2 & 0.952 & & & & EV2 & 0.719 & & & \\
\hline CRED3 & 0.951 & & & & EV3 & 0.702 & & & \\
\hline CRED4 & 0.934 & & & & EV4 & 0.901 & & & \\
\hline Entertainment & & 0.978 & 0.971 & 0.919 & EV5 & 0.851 & & & \\
\hline ENT1 & 0.945 & & & & Web design quality & & 0.954 & 0.936 & 0.839 \\
\hline ENT2 & 0.971 & & & & WDQ1 & 0.906 & & & \\
\hline ENT3 & 0.962 & & & & WDQ2 & 0.917 & & & \\
\hline ENT4 & 0.956 & & & & WDQ3 & 0.935 & & & \\
\hline Irritation & & 0.961 & 0.939 & 0.892 & WDQ4 & 0.905 & & & \\
\hline IRR1 & 0.947 & & & & Brand awareness & & 0.916 & 0.878 & 0.734 \\
\hline IRR2 & 0.949 & & & & BA1 & 0.770 & & & \\
\hline IRR3 & 0.938 & & & & BA2 & 0.861 & & & \\
\hline Incentives & & 0.929 & 0.885 & 0.814 & BA3 & 0.917 & & & \\
\hline INC1 & 0.850 & & & & BA4 & 0.871 & & & \\
\hline INC2 & 0.929 & & & & Purchase intention & & 0.957 & 0.932 & 0.881 \\
\hline INC3 & 0.925 & & & & PI1 & 0.913 & & & \\
\hline Advertising value & & 0.981 & 0.971 & 0.945 & PI2 & 0.958 & & & \\
\hline AV1 & 0.967 & & & & PI3 & 0.945 & & & \\
\hline AV2 & 0.976 & & & & & & & & \\
\hline AV3 & 0.973 & & & & & & & & \\
\hline
\end{tabular}

$\mathrm{p}<0.01)$ and web design quality $(\widehat{\beta}=0.035 ; \mathrm{p}>0.10)$ are not statistically significant. Therefore, hypotheses H2b, H3b, H4b, H5b, and H7a are supported, while hypotheses H1b, and H8a are not supported.

Third, brand awareness is not explained by $26 \%$ of the variation in the conceptual model. The hypotheses emotional value $(\widehat{\beta}=0.231 ; \mathrm{p}<0.01)$ and web design quality $(\widehat{\beta}=0.362 ; \mathrm{p}<0.01)$ are positively and statistically significant. Therefore, hypotheses $\mathrm{H} 6 \mathrm{~b}$ and $\mathrm{H} 8 \mathrm{c}$ are supported.

Finally, the model explains $68.3 \%$ of variance in purchase intention. The hypotheses of advertising value $(\widehat{\beta}=0.228$; $\mathrm{p}<0.01)$, web design quality $(\widehat{\beta}=0.099 ; \mathrm{p}<0.05)$, flow experience $(\widehat{\beta}=0.516$; $\mathrm{p}<0.01)$, and brand awareness $(\widehat{\beta}=0.109$; $\mathrm{p}<0.01)$ are statistically significant to explain the purchase intention. Therefore, H7b, H8b, H9 and H10 and are supported.

In summary, out of a total of 19 hypotheses in the model, 16 are supported and 3 are not.

\section{Discussion}

\subsection{Theoretical implications}

This research has three theoretical implications. First, advertising value was positively influenced by informativeness, credibility, entertainment, and incentives, which is consistent with previous findings (Ducoffe, 1995; Kim \& Han, 2014; Liu et al., 2012). Credibility was the strongest positive factor, followed by entertainment and informativeness. These results show that consumers perceive smartphone advertisements as a good source of product information and tend to consider it as being somewhat useful and enjoyable. In contrast, irritation negatively influences advertising value, meaning that consumers avoid irritating or annoying smartphone advertisements (Kim \& Han, 2014). In addition, this research failed to predict the effect of emotional value. That is, consumers do not have positive feelings about the brand advertised, and do not derive any benefit from the experience of smartphone advertisements.

Second, flow experience is positively influenced by credibility, entertainment, incentives, and advertising value. Informativeness and irritation had a negative influence, which is consistent with earlier research (Kim \& Han, 2014). Incentives are the strongest factor, followed by credibility and entertainment. To the contrary, the addition of web design quality did not have a significant impact, the effect of web design experience is not relevant for consumers while they are interacting with smartphone advertisements.

Third, the addition of emotional value and web design quality was revealed to explain brand awareness. These results show the importance of consumers developing an emotional bond with the brand they recognize in smartphone advertisements, and web design plays a crucial role in the perception of brand to consumers, a feeling that is reliable.

Table 4

AVE and correlations.

\begin{tabular}{|c|c|c|c|c|c|c|c|c|c|c|c|}
\hline & INF & CRED & ENT & IRR & INC & $\mathrm{AV}$ & $\mathrm{FE}$ & $\mathrm{EV}$ & WDQ & BA & PI \\
\hline Informativeness (INF) & 0.921 & & & & & & & & & & \\
\hline Credibility (CRED) & 0.790 & 0.939 & & & & & & & & & \\
\hline Entertainment (ENT) & 0.725 & 0.814 & 0.959 & & & & & & & & \\
\hline Irritation (IRR) & -0.402 & -0.477 & -0.550 & 0.944 & & & & & & & \\
\hline Incentives (INC) & 0.415 & 0.539 & 0.581 & -0.382 & 0.902 & & & & & & \\
\hline Advertising value (AV) & 0.687 & 0.784 & 0.767 & -0.497 & 0.646 & 0.972 & & & & & \\
\hline Flow experience (FE) & 0.518 & 0.682 & 0.699 & -0.491 & 0.698 & 0.741 & 0.894 & & & & \\
\hline Emotional value (EV) & 0.458 & 0.372 & 0.351 & -0.084 & 0.387 & 0.375 & 0.358 & 0.809 & & & \\
\hline Web design quality (WDQ) & 0.737 & 0.711 & 0.713 & -0.418 & 0.463 & 0.633 & 0.551 & 0.448 & 0.916 & & \\
\hline Brand awareness (BA) & 0.495 & 0.519 & 0.457 & -0.165 & 0.381 & 0.552 & 0.412 & 0.394 & 0.466 & 0.856 & \\
\hline Purchase intention (PI) & 0.578 & 0.668 & 0.658 & -0.452 & 0.642 & 0.733 & 0.785 & 0.360 & 0.579 & 0.493 & 0.939 \\
\hline
\end{tabular}




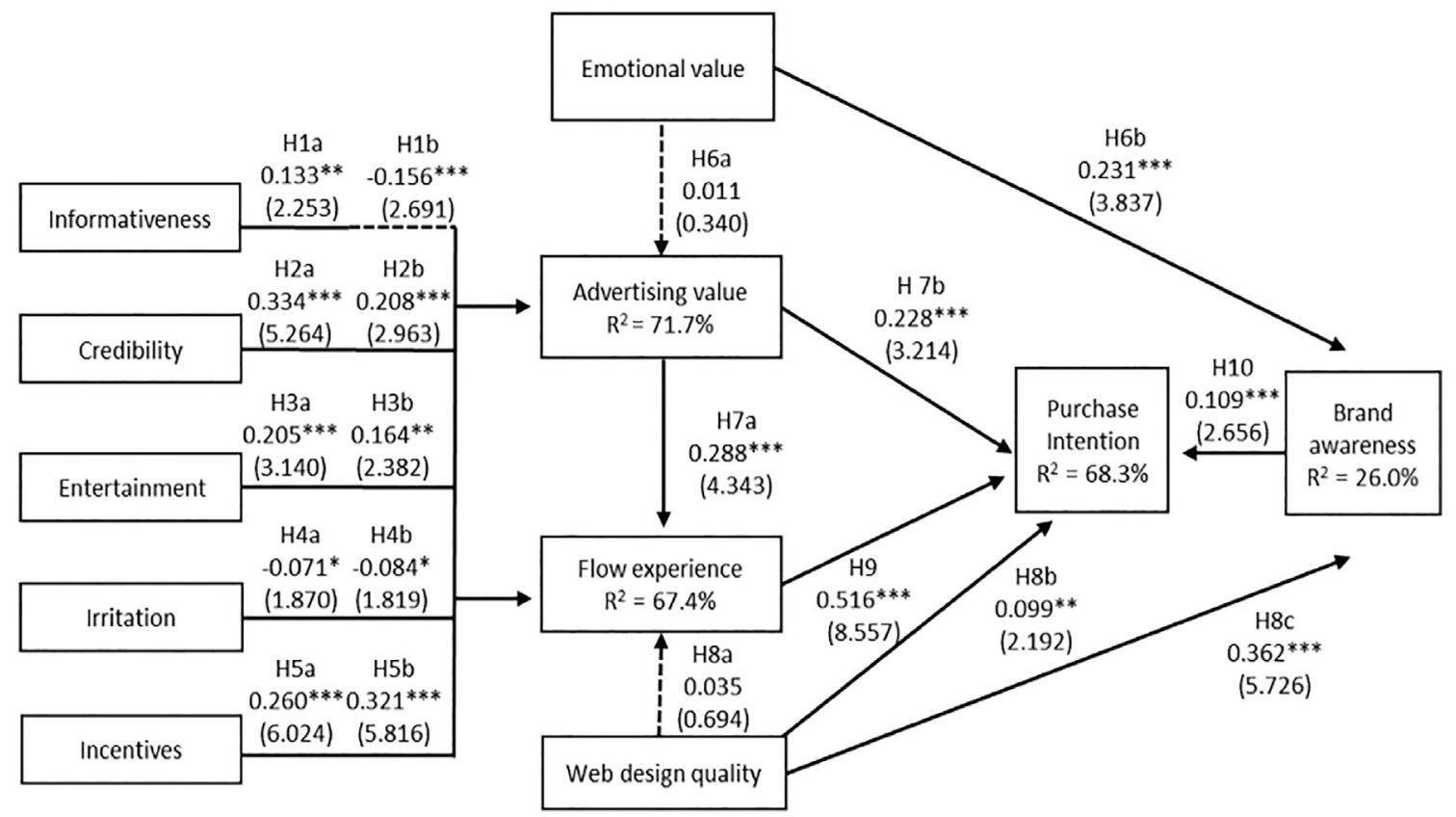

Fig. 2. - Structural model results.

Finally, results indicate that advertising value, flow experience, web design quality, and brand awareness are key factors to explain purchase intention in the context of smartphone advertisements. Table 5 illustrates the results demonstrated in this section.

\subsection{Practical implications}

Several practical implications can be drawn. First, while consumers view and engage with smartphone advertisements, valuable information that fulfils consumer needs should be delivered. Consumers enjoy focusing on the details of the product or service advertised. Marketers and advertisers can provide advertisements that meet consumer needs, and ensure they are part of the target communication.

Second, irritation is recognized by consumers as being annoying and intrusive with advertisements. Marketers and advertisers should consider if consumers are receptive to advertisements on smartphones, and allow the option for consumers to choose whether they want to receive them or not. This would contribute to making consumers feel less irritated, impatient, and advertisements being less intrusive.

Third, regarding the importance of emotional value on brand awareness, consumers become more engaged with the brand the more they are familiar with it. Advertisers should consider creating advertisements that

Table 5

Hypotheses conclusions.

\begin{tabular}{|c|c|c|c|c|}
\hline Hypo-theses & $\begin{array}{l}\text { Independent } \\
\text { variables }\end{array}$ & $\begin{array}{l}\text { Dependent } \\
\text { variables }\end{array}$ & Findings & Results \\
\hline H1a & Informativeness & $\rightarrow$ Advertising value & Positive and statistically significant $(\widehat{\beta}=0.133 ; \mathrm{p}<0.05)$ & Supported \\
\hline $\mathrm{H} 1 \mathrm{~b}$ & & $\rightarrow$ Flow experience & Negative and statistically significant $(\widehat{\beta}=-0.156 ; \mathrm{p}<0.01)$ & Not supported \\
\hline $\mathrm{H} 2 \mathrm{a}$ & Credibility & $\rightarrow$ Advertising value & Positive and statistically significant $(\widehat{\beta}=.334 ; p<0.01)$ & Supported \\
\hline $\mathrm{H} 2 \mathrm{~b}$ & & $\rightarrow$ Flow experience & Positive and statistically significant $(\widehat{\beta}=0.208 ; \mathrm{p}<0.01)$ & Supported \\
\hline H3a & Entertainment & $\rightarrow$ Advertising value & Positive and statistically significant $(\widehat{\beta}=0.205 ; \mathrm{p}<0.01)$ & Supported \\
\hline $\mathrm{H} 3 \mathrm{~b}$ & & $\rightarrow$ Flow experience & Positive and statistically significant $(\widehat{\beta}=0.164 ; \mathrm{p}<0.05)$ & Supported \\
\hline $\mathrm{H} 4 \mathrm{a}$ & Irritation & $\rightarrow$ Advertising value & Negative and statistically significant $(\widehat{\beta}=-0.071 ; \mathrm{p}<0.10)$ & Supported \\
\hline $\mathrm{H} 4 \mathrm{~b}$ & & $\rightarrow$ Flow experience & Negative and statistically significant $(\widehat{\beta}=-0.084 ; \mathrm{p}<0.10)$ & Supported \\
\hline $\mathrm{H} 5 \mathrm{a}$ & Incentives & $\rightarrow$ Advertising value & Positive and statistically significant $(\widehat{\beta}=0.260 ; \mathrm{p}<0.01)$ & Supported \\
\hline $\mathrm{H} 5 \mathrm{~b}$ & & $\rightarrow$ Flow experience & Positive and statistically significant $(\widehat{\beta}=0.321 ; \mathrm{p}<0.01)$ & Supported \\
\hline H6a & Emotional value & $\rightarrow$ Advertising value & Positive and statistically significant $(\widehat{\beta}=0.011 ; \mathrm{p}>0.10)$ & Not supported \\
\hline $\mathrm{H} 6 \mathrm{~b}$ & & $\rightarrow$ Brand awareness & Positive and statistically significant $(\widehat{\beta}=0.231 ; \mathrm{p}<0.01)$ & Supported \\
\hline $\mathrm{H7a}$ & Advertising value & $\rightarrow$ Flow experience & Positive and statistically significant $(\widehat{\beta}=0.288 ; \mathrm{p}<0.01)$ & Supported \\
\hline $\mathrm{H} 7 \mathrm{~b}$ & & $\rightarrow$ Purchase intention & Positive and statistically significant $(\widehat{\beta}=0.228 ; \mathrm{p}<0.01)$ & Supported \\
\hline H8a & & $\rightarrow$ Flow experience & Non-significant effect $(\widehat{\beta}=0.035 ; \mathrm{p}>0.10)$ & Not supported \\
\hline $\mathrm{H} 8 \mathrm{~b}$ & Wed design quality & $\rightarrow$ Purchase intention & Positive and statistically significant $(\widehat{\beta}=0.099 ; \mathrm{p}<0.05)$ & Supported \\
\hline $\mathrm{H} 8 \mathrm{c}$ & & $\rightarrow$ Brand awareness & Positive and statistically significant $(\widehat{\beta}=0.362 ; \mathrm{p}<0.01)$ & Supported \\
\hline H9 & Flow experience & $\rightarrow$ Purchase intention & Positive and statistically significant $(\widehat{\beta}=0.516 ; p<0.01)$ & Supported \\
\hline $\mathrm{H} 10$ & Brand awareness & $\rightarrow$ Purchase intention & Positive and statistically significant $(\widehat{\beta}=0.109 ; \mathrm{p}<0.01)$ & Supported \\
\hline
\end{tabular}


arouse emotions. Emotions are representative of consumers' feelings and the way they interact with the brand relies on the basis that smartphone advertisements' connection with consumers arouse emotions, allowing for positive brand recognition, perceiving it as relevant and valuable.

Fourth, advertisers should develop smartphone advertisements that easily engage consumers' attention. Brands should consider investing in better designed advertisements that make the experience of viewing advertisements more attractive. Web design makes a difference in consumer perception about the content and product or service information. Improving web design quality in smartphone advertisements should induce pleasure and satisfaction among consumers.

\subsection{Limitations and future research}

Our study has several limitations. First, the study was conducted with consumers of only one European country. Therefore, in order to overcome cultural and economic disparities, it would be interesting to implement it in other countries, and compare the findings. Second, brand awareness confirmed the influence on purchase intention and is one of the dimensions of brand equity. Thus, more effort is required to theoretically and empirically test the antecedents of brand equity that influences purchase intention. Third, web design quality was unsupported to explain flow experience and future studies should investigate the antecedents such as interactivity. Fourth, further research to understand the effect of emotional value on purchase intention would be welcome.

\section{Conclusions}

The contribution of this research was to identify the strongest factors influencing consumers' willingness to purchase products or services, after viewing advertisements on smartphones. For this purpose, we developed a model based on Ducoffe's web advertising model and flow experience theory. This study was the first to include emotional value, web design quality, and brand awareness. Based on a sample of 303 Portuguese respondents we empirically confirmed that for advertising value the facilitators were informativeness, credibility, entertainment, and incentives, while irritation and emotional value were inhibitors. These findings revealed that consumers consider smartphone advertising as being credible, enjoyable, a good reference of information for purchasing products, and offers the chance of obtain rewards. However, they may also perceive smartphone advertising as unwanted, intrusive, and annoying, and as a result, negative feelings arise toward the brand advertised. Flow experience was positively influenced by credibility, entertainment, incentives, and advertising value. Informativeness and irritation negatively influenced flow experience. These results may be driven by the fact that, as argued in the literature, consumers are starting to develop positive attitudes toward smartphone advertisements, as they are useful, valuable, believable, entertaining, and correctly deliver the details of the products. Nevertheless, when consumers do not obtain proper information, they recognize smartphone advertisements as irritating. Brand awareness was successfully explained by emotional value and web design quality. Brand awareness was confirmed to be crucial for consumers to recognize the brand, and consider purchasing of a brand's products or services. Finally, we concluded that purchase intention was successfully explained by advertising value, flow experience, web design quality, and brand awareness.

\section{Appendix A}

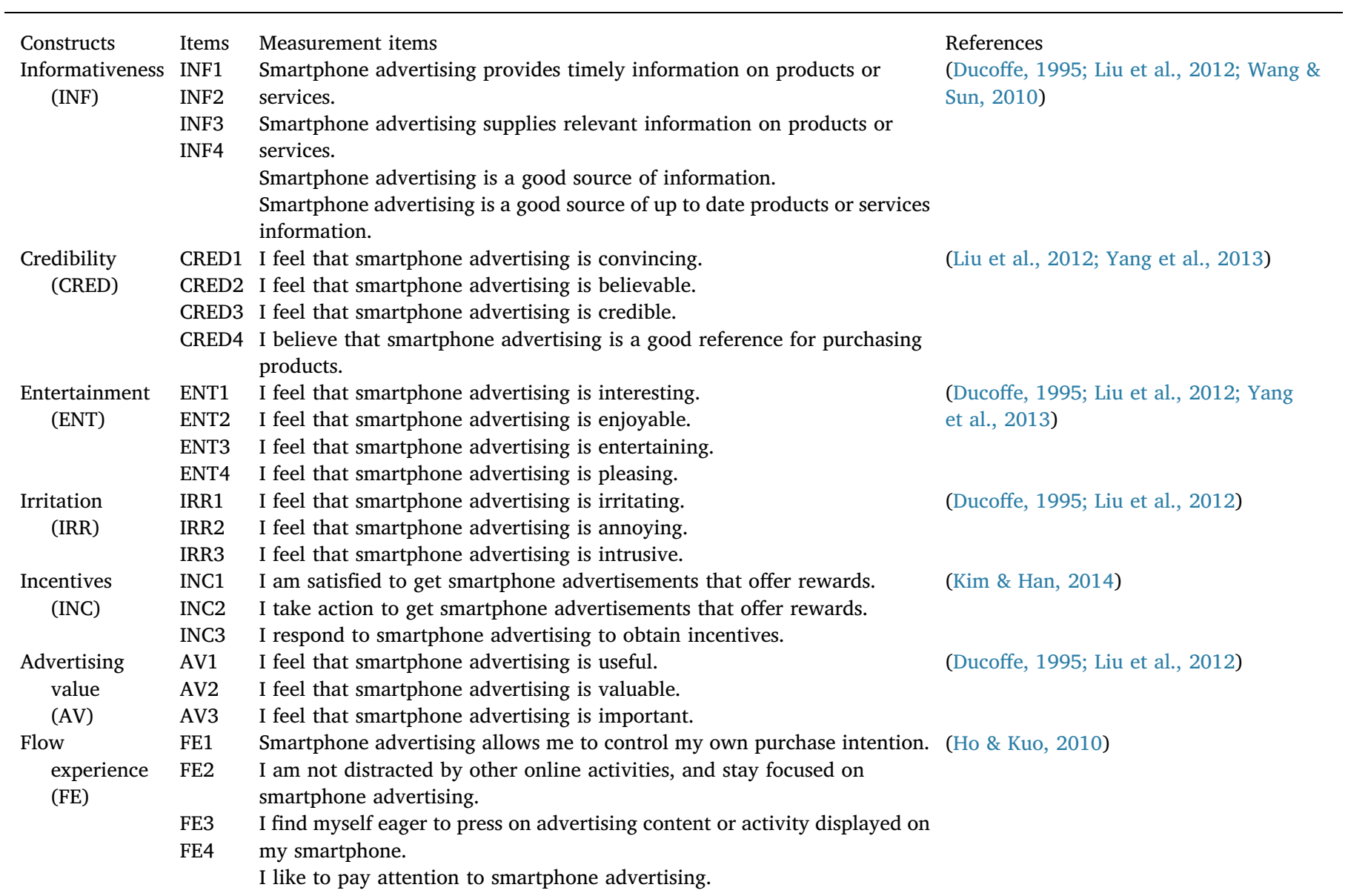


Purchase PI1 I find purchasing product/service advertised to be worthwhile.

intention PI2 I will frequently purchase product/service advertised in the future.

(PI) PI3 I will strongly recommend others to purchase product/service advertised.

Emotional EV1 Using smartphones makes me feel relaxed.

value EV2 I enjoy using smartphones.

(EV) EV3 The use of smartphones makes me want to use them.

EV4 Using smartphones makes me feel good.

EV5 Using smartphones gives me pleasure.

Web WDQ1 The web site looks attractive.

design WDQ2 The web site uses fonts properly.

quality WDQ3 The web site uses colours properly.

(WDQ) WDQ4 The web site uses multimedia features properly.

Brand

BA1 I have heard of this brand.

awareness BA2 This brand is what I first thought of.

(BA) BA3 This brand is very famous.

BA4 Most people know this brand.
(Hsu \& Lin, 2015; Kumar, Lee, \& Kim, 2009)

(Hsu \& Lin, 2015; Kumar et al., 2009)

(Ha \& Im, 2012)

(Wu \& Ho, 2014)

\section{References}

Agrebi, S., \& Jallais, J. (2015). Explain the intention to use smartphones for mobile shopping. Journal of Retailing and Consumer Services, 22, 16-23.

Aitken, R., Gray, B., \& Lawson, R. (2008). Advertising effectiveness from a consumer perspective. International Journal, 27(2), 279-297.

Balasubraman, S., Peterson, R., \& Jarvenpaa, S. (2002). Exploring the implications of Mcommerce for markets and marketing. Journal of the Academy of Marketing Science, 30(4), 348-361. http://dx.doi.org/10.1177/009207002236910.

Baptista, G., \& Oliveira, T. (2015). Understanding mobile banking: The unified theory of acceptance and use of technology combined with cultural moderators. Computers in Human Behavior, 50, 418-430. http://dx.doi.org/10.1016/j.chb.2015.04.024.

Brackett, L., \& Carr, B., Jr. (2001). Cyberspace advertising vs. other media: Consumer vs. mature student attitudes. Journal of Advertising Research, 41(5), 23-32.

Chen, P., \& Hsieh, H. (2012). Personalized mobile advertising: Its key attributes, trends, and social impact. Technological Forecasting and Social Change, 79(3), 543-557. http://dx.doi.org/10.1016/j.techfore.2011.08.011.

Chen, Y., Hsu, I., \& Lin, C. (2010). Website attributes that increase consumer purchase intention: A conjoint analysis. Journal of Business Research, 63(9-10), 1007-1014. http://dx.doi.org/10.1016/j.jbusres.2009.01.023.

Chen, H., Wigand, R., \& Nilan, M. (1998). Optimal flow experience in web navigation. Idea Group Publishing633-636.

Chin, W. (1998). The partial least squares approach to structural equation modeling. Modern Methods for Business Research, 295(2), 295-336.

Choi, Y., Hwang, J., \& McMillan, S. (2008). Gearing up for mobile advertising: A crosscultural examination of key factors that drive mobile messages home to consumers. Psychology and Marketing, 25(8), 756-768. http://dx.doi.org/10.1002/mar.

Coulter, R., Zaltman, G., \& Coulter, K. (2001). Interpreting consumer perceptions of advertising: An application of the Zaltman metaphor elicitation technique. Journal of Advertising, 30(4), 1-21. http://dx.doi.org/10.1080/00913367.2001.10673648.

Csikszentmihalyi, M. (1975). Play and intrinsic rewards. Journal of Humanistic Psychology, 15(3), 41-63.

Dai, B., Forsythe, S., \& Kwon, W. (2014). The impact of online shopping experience on risk perceptions and online purchase intentions: Does product category matter? Journal of Electronic Commerce Research, 15(1), 13.

Dehghani, M., \& Tumer, M. (2015). A research on effectiveness of Facebook advertising on enhancing purchase intention of consumers. Computers in Human Behavior, 49, 597-600.

Derks, D., Bakker, A., Peters, P., \& van Wingerden, P. (2016). Work-related smartphone use, work-family conflict and family role performance: The role of segmentation preference. Human Relations; Studies Towards the Integration of the Social Sciences, 69(5), 1045-1068. http://dx.doi.org/10.1177/0018726715601890.

Ducoffe, R. (1995). How consumers assess the value of advertising. Vol. 17, 1-18.

Ducoffe, R. (1996). Advertising value and advertising on the web. Journal of Advertising Research, 36(5), 21-35. http://dx.doi.org/10.1080/135272600750036364.

Edell, J., \& Burke, M. (1987). The power of feelings in understanding advertising effects. Journal of Consumer Research, 14(3), (421-421) https://doi.org/10.1086/209124.

Elliott, M., \& Speck, P. (1998). Consumer perceptions of advertising clutter and its impact across various media. Journal of Advertising Research, 1(February), 29-41.

Flanagin, A., Metzger, M., Pure, R., Markov, A., \& Hartsell, E. (2014). Mitigating risk in ecommerce transactions: Perceptions of information credibility and the role of usergenerated ratings in product quality and purchase intention. Electronic Commerce Research, 14(1), 1-23.

Fornell, C., \& Larcker, D. (1981). Structural equation models with unobservable variables and measurement error: Algebra and statistics. Journal of Marketing Research, 18(3), 382-388. http://dx.doi.org/10.2307/3150980.

Gartner (2016). Gartner Says Worldwide Smartphone Sales Grew 3.9 Percent in First Quarter of 2016 [Press release]. Retrieved fromhttps://www.gartner.com/newsroom/id/ 3323017.

Grewal, D., Bart, Y., Spann, M., \& Zubcsek, P. (2016). Mobile advertising: A framework and research agenda. Journal of Interactive Marketing, 34, 3-14.
Ha, Y., \& Im, H. (2012). Role of web site design quality in satisfaction and word of mouth generation. Journal of Service Management, 23(1), 79-96. http://dx.doi.org/10.1108/ 09564231211208989.

Ha, S., \& Stoel, L. (2009). Consumer e-shopping acceptance: Antecedents in a technology acceptance model. Journal of Business Research, 62(5), 565-571. http://dx.doi.org/ 10.1016/j.jbusres.2008.06.016.

Hair, J., \& Anderson, R. (2010). Multivariate data analysis. Prentice Hall.

Henseler, J., Ringle, C. M., \& Sarstedt, M. (2015). A new criterion for assessing discriminant validity in variance-based structural equation modeling. Journal of the Academy of Marketing Science, 43(1), 115-135.

Henseler, J., Ringle, C., \& Sinkovics, R. (2009). The use of partial least squares path modeling in international marketing. Advances in International Marketing, 20(1), 277-319. http://dx.doi.org/10.1016/0167-8116(92)90003-4.

Ho, L., \& Kuo, T. (2010). How can one amplify the effect of e-learning? An examination of high-tech employees' computer attitude and flow experience. Computers in Human Behavior, 26(1), 23-31. http://dx.doi.org/10.1016/j.chb.2009.07.007.

Hoffman, D., \& Novak, T. (1996). Marketing in hypermedia environment foundations: Conceptual foundations. Journal of Marketing, 60(3), 50-68. http://dx.doi.org/10. $2307 / 1251841$.

Hoffman, D., \& Novak, T. (2009). Flow online: Lessons learned and future prospects. Journal of Interactive Marketing, 23(1), 23-34. http://dx.doi.org/10.1016/j.intmar. 2008.10.003.

Hossein, M. (2015). A study of mobile banking usage in Iran. The International Journal of Bank Marketing, 33(6), 733-759. http://dx.doi.org/10.1108/IJBM-08-2014-0114.

Hoyer, W., \& Brown, S. (1990). Effects of brand awareness on choice for a common, repeat-purchase product. Journal of Consumer Research, 17(2), 141-148.

Hsia, J., Chang, C., \& Tseng, A. (2014). Effects of individuals' locus of control and computer self-efficacy on their e-learning acceptance in high-tech companies. Behaviour \& Information Technology, 33(1), 51-64.

Hsu, C., \& Lin, J. (2015). What drives purchase intention for paid mobile apps?-An expectation confirmation model with perceived value. Electronic Commerce Research and Applications, 14(1), 46-57. http://dx.doi.org/10.1016/j.elerap.2014.11.003.

Hyun, S., Kim, W., \& Lee, M. (2011). The impact of advertising on patrons' emotional responses, perceived value, and behavioral intentions in the chain restaurant industry: The moderating role of advertising-induced arousal. International Journal of Hospitality Management, 30(3), 689-700. http://dx.doi.org/10.1016/j.ijhm.2010.10. 008.

Joo, J., \& Sang, Y. (2013). Exploring Koreans' smartphone usage: An integrated model of the technology acceptance model and uses and gratifications theory. Computers in Human Behavior, 29(6), 2512-2518. http://dx.doi.org/10.1016/j.chb.2013.06.002.

Kim, Y., \& Han, J. (2014). Why smartphone advertising attracts customers: A model of web advertising, flow, and personalization. Computers in Human Behavior, 33, 256-269. http://dx.doi.org/10.1016/j.chb.2014.01.015.

Kim, H., \& Niehm, L. S. (2009). The impact of website quality on information quality, value, and loyalty intentions in apparel retailing. Journal of Interactive Marketing, 23(3), 221-233. http://dx.doi.org/10.1016/j.intmar.2009.04.009.

Ko, H., Cho, C., \& Roberts, M. (2005). Internet uses and gratifications: A structural equation model of interactive advertising. Journal of Advertising, 34(2), 57-70.

Korgaonkar, P., \& Wolin, L. (1999). A multivariate analysis of web usage. Journal of Advertising Research, 39, 53-68.

Kumar, A., Lee, H., \& Kim, Y. (2009). Indian consumers' purchase intention toward a United States versus local brand. Journal of Business Research, 62(5), 521-527. http:// dx.doi.org/10.1016/j.jbusres.2008.06.018.

Li, D., \& Browne, G. J. (2006). The role of need for cognition and mood in online flow experience. The Journal of Computer Information Systems, 46(3), 11-17.

Liu, C., Sinkovics, R., Pezderka, N., \& Haghirian, P. (2012). Determinants of consumer perceptions toward mobile advertising - a comparison between Japan and Austria. Journal of Interactive Marketing, 26(1), 21-32. http://dx.doi.org/10.1016/j.intmar. 2011.07.002.

Mackenzie, S., \& Lutz, R. (1989). An empirical examination of the structural antecedents of attitude toward the ad in an advertising pretesting context. Journal of Marketing, 
53(2), 48-65. http://dx.doi.org/10.2307/1251413.

Newzoo (2017). Top 50 countries by smartphone users and penetration (Retrieved from Newzoo Rankings) https://newzoo.com/insights/rankings/top-50-countries-bysmartphone-penetration-and-users/.

Novak, T., Hoffman, D., \& Yung, Y. (2000). Measuring the customer experience in online environments: A structural modeling approach. Marketing Science, 19(1), 22-44. http://dx.doi.org/10.1287/mksc.19.1.22.15184.

Okazaki, S. (2004). How do Japanese consumers perceive wireless ads? A multivariate analysis. International Journal of Advertising, 23(4), 429-454. http://dx.doi.org/10. 1080/02650487.2004.11072894.

Park, N., Kim, Y. C., Shon, H. Y., \& Shim, H. (2013). Factors influencing smartphone use and dependency in South Korea. Computers in Human Behavior, 29(4), 1763-1770. http://dx.doi.org/10.1016/j.chb.2013.02.008.

Ringle, C., Wende, S., \& Will, A. (2005). SmartPLS 2.0. Hamburg: SmartPLS. www. smartpls.de.

Scharl, A., Dickinger, A., \& Murphy, J. (2005). Diffusion and success factors of mobile marketing. Electronic Commerce Research and Applications, 4(2), 159-173. http://dx doi.org/10.1016/j.elerap.2004.10.006.

See-To, E., \& Ho, K. (2014). Value co-creation and purchase intention in social network sites: The role of electronic word-of-mouth and trust-a theoretical analysis. Computers in Human Behavior, 31, 182-189.

Shavitt, S., Lowrey, P., \& Haefner, J. (1998). Public attitudes toward advertising: More favorable than you might think. Journal of Advertising Research, 38(4), 7-22.

Shen, G. C.-C. (2015). Users' adoption of mobile applications: Product type and message framing's moderating effect. Journal of Business Research, 68(11), 2317-2321.

Sternthal, B., \& Craig, S. (1973). Humor in advertising. Journal of Marketing, 37(4), 12-18. http://dx.doi.org/10.2307/1250353.

Stewart, D., \& Pavlou, P. (2002). From consumer response to active consumer: Measuring the effectiveness of interactive media. Journal of the Academy of Marketing Science, 30(4), 376-396. http://dx.doi.org/10.1177/009207002236912.

Sweeney, J., \& Soutar, G. (2001). Consumer perceived value: The development of a multiple item scale. Journal of Retailing, 77(2), 203-220. http://dx.doi.org/10.1016/ S0022-4359(01)00041-0.

Tenenhaus, M., Vinzi, V., Chatelin, Y., \& Lauro, C. (2005). PLS path modeling. Computational Statistics and Data Analysis, 48(1), 159-205.
Tsang, M., Ho, S., \& Liang, T. (2004). Consumer attitudes toward mobile advertising: An empirical study. International Journal of Electronic Commerce, 8(3), 65-78. http://dx. doi.org/10.1080/10864415.2004.11044301.

Varnali, K., Yilmaz, C., \& Toker, A. (2012). Predictors of attitudinal and behavioral outcomes in mobile advertising: A field experiment. Electronic Commerce Research and Applications, 11(6), 570-581. http://dx.doi.org/10.1016/j.elerap.2012.08.002.

Wang, Y., \& Sun, S. (2010). Examining the role of beliefs and attitudes in online advertising. International Marketing Review, 27(1), 87-107. http://dx.doi.org/10.1108/ 02651331011020410.

Washburn, J., \& Plank, R. (2002). Measuring brand equity: An evaluation of a consumerbased brand equity scale. Journal of Marketing Theory and Practice, 10(1), 46-62.

Wu, S., \& Ho, L. (2014). The influence of perceived innovation and brand awareness on purchase intention of innovation product - an example of iPhone. International Journal of Innovation and Technology Management, 11(4), http://dx.doi.org/10.1142/ S0219877014500266.

Wu, P., Yeh, G., \& Hsiao, C. (2011). The effect of store image and service quality on brand image and purchase intention for private label brands. Australasian Marketing Journal, 19(1), 30-39. http://dx.doi.org/10.1016/j.ausmj.2010.11.001.

Yang, B., Kim, Y., \& Yoo, C. (2013). The integrated mobile advertising model: The effects of technology- and emotion-based evaluations. Journal of Business Research, 66(9), 1345-1352. http://dx.doi.org/10.1016/j.jbusres.2012.02.035.

Yeh, C., Wang, Y., \& Yieh, K. (2016). Predicting smartphone brand loyalty: Consumer value and consumer-brand identification perspectives. International Journal of Information Management, 36(3), 245-257. http://dx.doi.org/10.1016/j.ijinfomgt. 2015.11.013.

Zhang, J., \& Mao, E. (2008). Understanding the acceptance of mobile SMS advertising among young Chinese consumers. Psychology and Marketing, 25(8), 787-805. http:// dx.doi.org/10.1002/mar.

Zhu, D., Chang, Y., \& Luo, J. (2016). Understanding the influence of C2C communication on purchase decision in online communities from a perspective of information adoption model. Telematics and Informatics, 33(1), 8-16. http://dx.doi.org/10.1016/ j.tele.2015.06.001.

Zubcsek, P., Katona, Z., \& Sarvary, M. (2017). Predicting mobile advertising response using consumer colocation networks. Journal of Marketing, 81(4), 109-126. 